\title{
Cell cycle control of pituitary development and disease
}

\author{
Victor Quereda and Marcos Malumbres \\ Cell Division and Cancer Group, Centro Nacional de Investigaciones Oncológicas (CNIO), Melchor Fernández Almagro 3, E-28029 Madrid, Spain
}

(Correspondence should be addressed to M Malumbres; Email: malumbres@cnio.es)

\begin{abstract}
The pituitary gland regulates diverse physiological functions, including growth, metabolism, reproduction, stress response, and ageing. Early genetic models in the mouse taught us that the pituitary is highly sensitive to genetic alteration of specific cell cycle regulators such as the retinoblastoma protein ( $p R B)$ or the cell cycle inhibitor p27 Kip1. The molecular analysis of human pituitary neoplasias has now corroborated that cell cycle deregulation is significantly implicated in pituitary tumorigenesis. In particular, proteins involved in cyclin-dependent kinase regulation or the pRB pathway are altered in nearly all human pituitary tumors. Additional cell cycle regulators such as PTTG1/securin may have critical roles in promoting genomic instability in pituitary neoplasias. Recent experimental data suggest that these cell cycle regulators may have significant implications in the biology of putative progenitor cells and pituitary homeostasis. Understanding how cell cycle regulation controls pituitary biology may provide us with new therapeutic approaches against pituitary diseases.
\end{abstract}

Journal of Molecular Endocrinology (2009) 42, 75-86

\section{Introduction}

The pituitary gland is a central endocrine organ that regulates basic physiological functions including growth, reproduction, and metabolic homeostasis. The mammalian pituitary is composed of three lobes: the posterior pituitary (PP), the intermediate lobe (IL, atrophic in humans), and the anterior pituitary (AP). The versatile endocrine functions of the gland are carried out by six cell types residing in the AP and IL of the pituitary gland. These cell types are defined by the hormone they produce and secrete: corticotropes producing ACTH, thyrotropes secreting TSH, somatotropes secreting $\mathrm{GH}$, lactotropes that produce prolactin, gonadotropes secreting $\mathrm{LH}$, and $\mathrm{FSH}$, and the IL-specific melanotropes secreting MSH (Fig. 1). The adult pituitary arises from progenitors of a neuroectodermic primordium known as Rathke's Pouch in a temporal and spatial-specific fashion during pituitary development (Melmed 2003, Zhu et al. 2007). By embryonic day (E) $9 \cdot 5$, specific signaling gradients induce the formation of the Rathke's Pouch from the oral ectoderm. The major proliferation phase and the positional determination and lineage commitment of the pituitary take place by mid-gestation (E11.5-E13.5) and the gland is not terminally differentiated till birth. Major pathways implicated in the development of the pituitary include the Notch and Wnt regulatory networks, which are mainly active in the early phases of pituitary organogenesis and are essential for the emergence of somatotropes, lactotropes, and thyrotropes (Zhu et al. 2007). The regulation of the proliferative ability of pituitary cells in adulthood is not well established, although different classes of stem/progenitor cells have been postulated (Vankelecom 2007). A side population that efficiently excludes the Hoechst 33342 dye has been shown to segregate with sphereforming cells in the pituitary (Chen et al. 2005). Pituitary colony-forming cells that display notable clonogenic potential have also been isolated (Lepore et al. 2005). More recently, stem-cell specific markers such as SOX2+, SOX9, or OCT4 in addition to other epithelial markers have been found in a single-cell layer in the marginal zone suggesting the presence of stem/progenitor cells that may contribute to cell renewal in the adult pituitary (Fauquier et al. 2008, Garcia-Lavandeira et al. 2008, Gleiberman et al. 2008).

\section{Control of the cell cycle by cyclin-depen- dent kinases and their regulators}

The cell cycle is the process by which cells divide into daughter cells. Cell division is traditionally divided into four phases: $\mathrm{S}$ phase (synthesis of DNA) in which is produced the duplication of the genome, M phase 


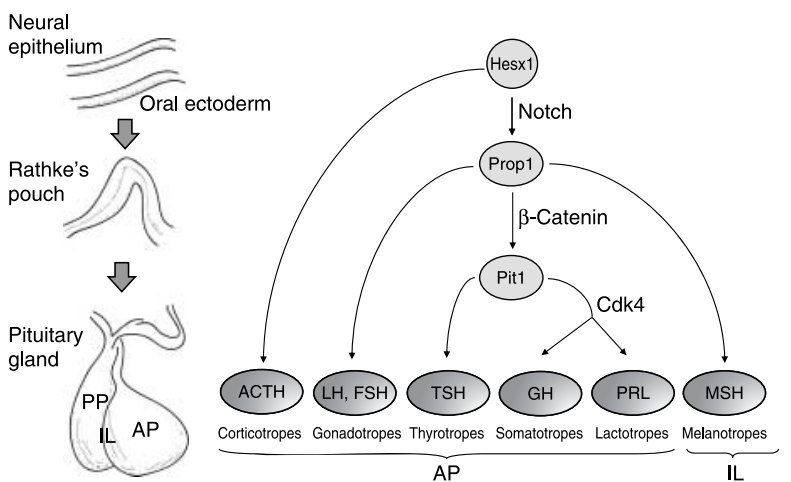

Figure 1 Development of pituitary and generation of hormoneproducing cells from progenitors. Some representative transcription factors and signaling pathways are indicated. The cell cycle regulator CDK4 may be involved in the post-natal production of some AP cells such as somatotropes and lactotropes. The requirement for CDK4 in other pituitary cells is not clear as the whole pituitary is smaller in Cdk4-null mice. PP, posterior pituitary; $\mathrm{IL}$, intermediate lobe; and AP, anterior pituitary.

(mitosis) in which the genetic material is segregated into two identical daughter cells, and two phases of growing and transition, called G (gap) phases (Fig. 2). G1 phase occurs before S phase; and G2 precedes mitosis. In mammalian cells, this process is driven by several protein kinases that regulate progression through the various phases of the cell cycle. Among these kinases, cyclindependent kinases (CDKs) are critical regulators of the transition through the different phases of the cell cycle (Malumbres \& Barbacid 2005). CDK activity is modulated by fluctuations in the cellular concentration of their activators (cyclins) or inhibitors (CDK inhibitors or CKIs), which are regulated by specific transcriptional induction by mitogenic and anti-mitogenic pathways and proteolysis by the ubiquitin-proteosome system. A variety of cyclin and CDK complexes participate in the regulation of G1/S or G2/M transitions. D-type cyclins (D1, D2, and D3) act as sensors of multiple mitogenic signals to activate CDK4 and CDK6 and to facilitate the progression during G1. CDK2-cyclin E (E1 and E2) complexes become active at the end of G1 and participate in the transition from G1 to S phase. E-type cyclins are substituted by A-type cyclins (A1, A2) to activate CDK2 and CDK1 at the end of S phase and during G2. Finally, the mitotic complex formed of CDK1-cyclin B (mostly B1 and B2) is involved in the progression through G2 and entry into $\mathrm{M}$ phases.

The specific inhibitors of CDKs (CKIs) also play a major role in the cell cycle as mediators of antimitogenic signals or checkpoint responses. They counteract CDK function, either by blocking their activation, or by impairing substrate/ATP access. There are two families of CKIs, the INK4 family and the Cip/Kip family. The INK4 family $\left(\mathrm{p} 16^{\mathrm{INK} 4 \mathrm{a}}, \mathrm{p} 15^{\mathrm{INK} 4 \mathrm{~b}}, \mathrm{p} 18^{\mathrm{INK} 4 \mathrm{c}}\right.$, and $\mathrm{p} 19^{\mathrm{INK} 4 \mathrm{~d}}$ ) inhibits progression through $\mathrm{G} 1 / \mathrm{S}$ by binding CDK4 and CDK6. By contrast, members of the Cip/Kip family (p21 ${ }^{\mathrm{Cip} 1}$, p2 $7^{\mathrm{Kip} 1}$, and $\mathrm{p} 57^{\mathrm{Kip} 2}$ ) have different roles depending on the $\mathrm{CDK}$-cyclin complex they bind to. Association to CDK2 and CDK1 complexes blocks their kinase activity, whereas the role of Cip or

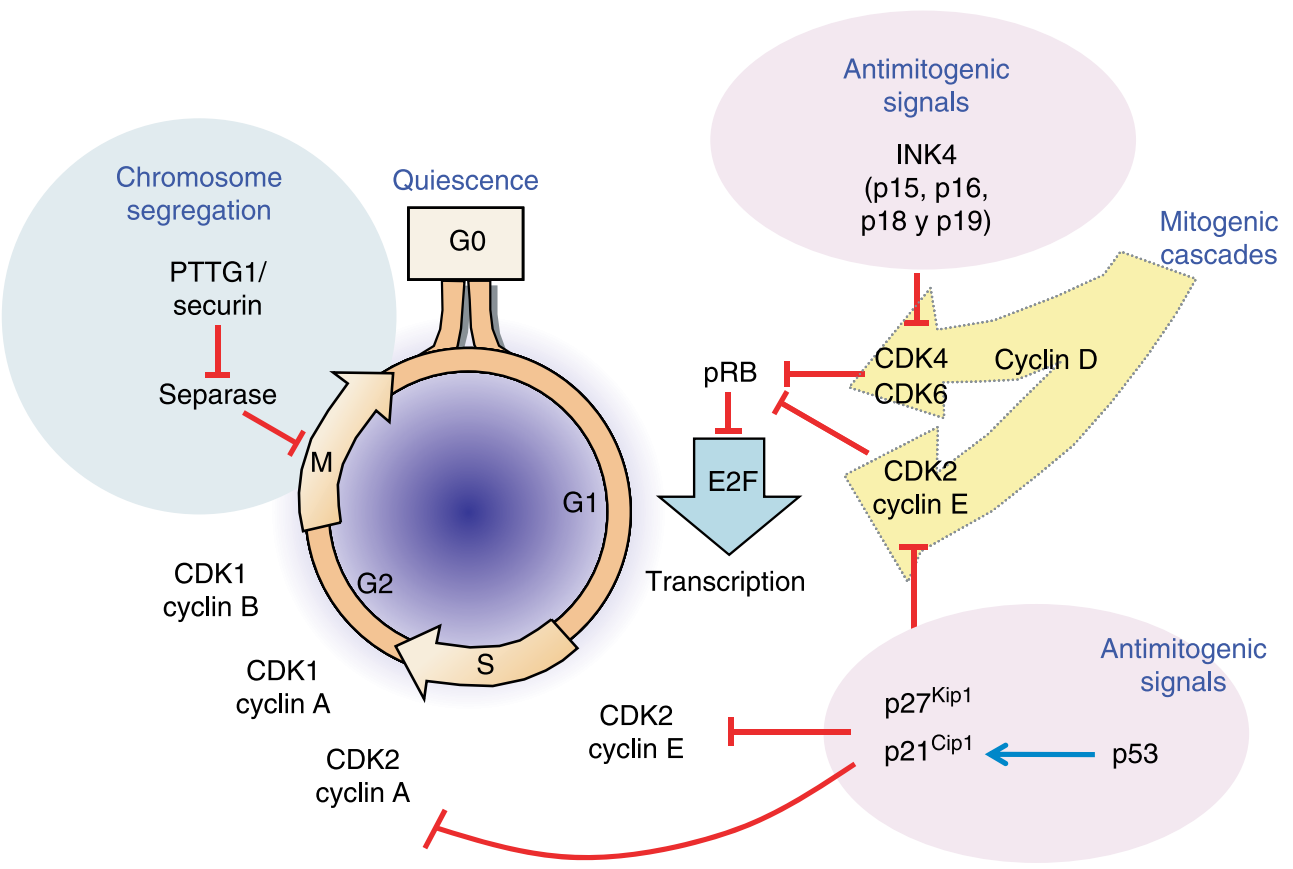

Figure 2 Control of the cell division cycle by major regulators involved in pituitary biology. S, DNA synthesis; M, mitosis; G1 and G2 correspond to 'gap' phases. Quiescence is frequently referred to as G0. 
Kip binding to CDK4-cyclin D or CDK6-cyclin D complexes is unclear (Malumbres \& Barbacid 2005).

The primary substrates of the CDKs in G1 progression are the members of the retinoblastoma protein family (pRB). pRB negatively regulates entry into the cell cycle and G1/S progression (Malumbres \& Barbacid 2001). pRB binds to the transcription factor family E2F to target cell cycle-specific genes for repression. In non-cycling cells, pRB is hypo-phosphorylated and this active form is able to repress cell cycle progression. CDK-cyclin mediated phosphorylation of $\mathrm{pRB}$ provokes its release from $\mathrm{E} 2 \mathrm{~F}$ factors that are then active to induce the expression of cell cycle genes required for $\mathrm{S}$ and $\mathrm{M}$ phases.

\section{Pituitary function and mouse models of cell cycle deregulation}

Little is known about the implication of cell cycle regulators in pituitary gland development. However, in the last years, several mouse models of cell cycle regulators, such as pRB, CDKs, or CKIs, have suggested that some endocrine tissues such as the pituitary gland are critical targets of cell cycle deregulation in cancer and other diseases.

The initial link between cell cycle regulation and the pituitary comes from the seminal genetic analysis of pRB in the mouse (Clarke et al. 1992, Jacks et al. 1992, Lee et al. 1992). In contrast to humans, in whom individuals who inherit one defective copy of $\mathrm{pRB}$ gene have a roughly 90\% likelihood of developing retinoblastoma at an early age (Matsunaga 1980), mice heterozygous for $\mathrm{pRB}$ did not develop retinoblastoma but instead developed pituitary tumors by the age of 12 months (Jacks et al. 1992; Table 1). Tumor incidence and histological phenotype of the tumors was highly dependent on the mouse strain suggesting additional modifier genes in pituitary tumor development (Leung et al. 2004). Tumor incidence provoked by the partial deletion of $\mathrm{pRB}$ is partially reverted by a mutation in $\mathrm{pRB}$ effectors such as E2f1 (Yamasaki et al. 1998) or E2f4 (Lee et al.

Table 1 Mouse models of cell cycle-related proteins involved in pituitary biology

Pituitary phenotype

\section{Model}

Pituitary hyperplasia $\mathrm{pRb}^{+1-}$

$\mathrm{pRb}^{+/-} ; \mathrm{E} 2 \mathrm{f}-1^{-1-}$

$\mathrm{pRB}^{+/-} ; \mathrm{E} 2 \mathrm{f}-4^{-1-}$

$\mathrm{p} 27^{-1-}$

$\mathrm{p} 27^{\mathrm{CK}-/ \mathrm{CK}-}$

p27 $7^{-1-} ; \mathrm{Cdk}^{-/-}$

$\mathrm{pRb}^{+/-} ; \mathrm{p} 27^{-1-}$

$\mathrm{p} 18^{-1}$

p16 $16^{-/-}$p $18^{-/-}$

$\mathrm{p} 15^{-/-} ; \mathrm{p} 18^{-/-}$

$\mathrm{p} 19^{-/-} ; \mathrm{p} 18^{-1-}$

p21 ${ }^{-1-} ; \mathrm{p} 18^{-/-}$

p27 ${ }^{-1-} ;{\mathrm{p} 18^{-1-}}^{-1-}$

$\mathrm{pRB}^{+/-} ;{\mathrm{p} 21^{-/-}}^{-1}$

$\mathrm{Cdk} 4^{\mathrm{R} 24 \mathrm{C} / \mathrm{R} 24 \mathrm{C}}$

K5-Cdk4; p2 ${ }^{-1-}$

Cdk4 ${ }^{\text {R24C/R24C; }}$ 22 ${ }^{-1-}$

$\mathrm{pRB}^{+/-} ; \mathrm{Pttg}^{-/-}$

$\mathrm{pRB}^{+/-} ;$aGSU.PTTG1

Pituitary hypoplasia

Cdk $^{-1-}$

Securin $^{-1-}$

ND, Not determined.

Incidence (\%)

Latency (months)

References

IL tumors

IL tumors. Decreased versus $p R B$ mutants

IL tumors. Decreased versus $p R B$ mutants

IL tumors

IL tumors

IL tumors. No differences versus

P27 ${ }^{-1-} ;$ Cdk2 $^{+1+}$

Cooperation in IL tumors

Tumors in IL and AP

IL tumors. Shorter latency versus p18 mutants

No differences versus $p 18$ mutants

No differences versus $\mathrm{p} 18$ mutants

Cooperation in IL tumors

$\mathrm{IL}$ and AP undifferentiated tumors

IL tumors

AP tumors

Cooperation in IL tumors

Strong cooperation and undifferentiated tumors

IL tumors with decreased incidence versus $p R B$ mutants

Overexpression of securin cooperates in AP tumors

Defective proliferation and endocrine cell numbers

Hypoplastic pituitary
$100 \quad 16$

$62 \quad 18$

$78 \quad 20$

$100 \quad 12$

$75 \quad 10 \cdot 7$

$100 \quad 12$

$50-15$

$50-10$

$50 \quad 15$

$50 \quad 15$

$90 \quad 13$

$100 \quad 3.5$

$100 \quad 12$

$25 \quad 15$

$100 \quad 3$

$100 \quad 2$

$30 \quad 13$

13

16

Postnatal

ND

100

ND
$90 \quad 7$

Jacks et al. (1992)

Yamasaki et al. (1998)

Lee et al. (2002)

Kiyokawa et al. (1996) and Nakayama et al. (1996)

Besson et al. (2007)

Martin et al. (2005)

Park et al. (1999)

Franklin et al. (1998)

Ramsey et al. (2007)

Latres et al. (2000)

Zindy et al. (2001)

Franklin et al. (2000)

Franklin et al. (1998)

Brugarolas et al. (1998)

Rane et al. (2002) and

Sotillo et al. (2001)

Macias et al. (2008)

Sotillo et al. (2005)

Chesnokova et al. (2005)

Donangelo et al. (2006)

Melmed (2003) 
2002), indicating the relevance of the $\mathrm{pRB} / \mathrm{E} 2 \mathrm{~F}$ pathway in pituitary tumorigenesis. The sole overexpression of another E2F family member, E2f3, is not sufficient to produce pituitary tumors, although these transgenic mice develop pituitary hyperplasia (Lazzerini Denchi et al. 2005).

The genetic analysis of $\mathrm{pRB}$ in the mouse clearly demonstrated a tumor suppressor function for this protein, and specifically in endocrine organs such as the pituitary. By that time, pRB function in the cell cycle was not fully explored and the relationship with the pituitary was not obvious. More than 15 years later, the reasons for the special sensitivity of endocrine tissues and particularly the pituitary, to pRB lost are not understood yet. However, this close relationship is not restricted to pRB protein. In 1996, three groups reported multiple organ hyperplasia, including pituitary tumors in p27 $7^{\mathrm{Kip} 1}$ mutant mice (Fero et al. 1996, Kiyokawa et al. 1996, Nakayama et al. 1996). As in the pRB mutants, p27 $7^{\mathrm{Kip} 1}$-deficient mice developed pituitary tumors by the age of 12 months (Kiyokawa et al. 1996, Nakayama et al. 1996). Although, in both cases the animals developed IL tumors, they present differential patterns in both the histological phenotype and the gene profile expression (Chien et al. 2007). Soon after, a significant incidence of pituitary tumors was described in mice deficient in another cell cycle inhibitor, the member of the INK4 family $\mathrm{p} 18^{\mathrm{INK} 4 \mathrm{c}}$. Fifty percent of these animals developed aggressive pituitary tumors mostly from the IL by 15 months, although some tumors originated from the AP (Franklin et al. 1998). Deficiency in either of the other INK4 proteins, p16 $6^{\mathrm{INK} 4 \mathrm{a}}$, p $15^{\mathrm{INK} 4 \mathrm{c}}$, or $\mathrm{p} 19^{\mathrm{INK} 4 \mathrm{~d}}$ does not result in pituitary tumors. However, genetic ablation of both $\mathrm{p} 16^{\mathrm{INK} 4 \mathrm{a}}$ and $\mathrm{p} 18^{\mathrm{INK} 4 \mathrm{c}}$ cooperates both in the incidence and the latency of the development of the pituitary tumors (median survival of 10 months; Ramsey et al. 2007). No cooperation in pituitary tumor suppression is observed between $\mathrm{p} 18^{\mathrm{INK} 4 \mathrm{c}}$ and $\mathrm{p} 15^{\mathrm{NKK} 4 \mathrm{~b}}$ (Latres et al. 2000) or p19 $9^{\text {INK4d }}$ (Zindy et al. 2001).

INK4 proteins specifically inhibit CDK4 and CDK6 kinases by competing with the obligate activator of these kinases, the cyclins. The relevance of INK4 proteins as key inhibitor of CDK4 and CDK6 is highlighted by a specific mutation in CDK4 (Arg24 to Cys) that prevents inhibition of this kinase by INK4 proteins. This mutation has been observed in both hereditary and spontaneous melanoma with low incidence (Malumbres \& Barbacid 2001). When a Cdk4 R24C mutant protein is expressed in the mouse in substitution of the endogenous wild-type protein, these knock-in mice develop multiple tumors including frequent endocrine and mesenchymal tumors (Sotillo et al. 2001, Rane et al. 2002). Interestingly, pituitary tumors are also frequent (around 25\% in all the studies) in these knock-in mice suggesting the relevance of CDK4 kinase activity in these neoplasias. Most of these pituitary tumors originated in the AP with an average latency of around 15 months.

\section{One or several cell cycle pathways in pituitary tumorigenesis?}

The former models suggest a clear relevance of the CDK (and their inhibitors INK4 or KIP)/pRB pathway in pituitary tumorigenesis. However, the results obtained from the combination of some of these mutations in the mouse suggest a more complex molecular network. The combined deletion of $\mathrm{pRB}$ and $\mathrm{p} 27^{\mathrm{Kip} 1}$ results in shorter latency of pituitary tumors in p27 $(-/-)$; pRb $(+/-)$ mice (Park et al. 1999). In addition, the expression of $\mathrm{p} 27^{\mathrm{Kip} 1} \mathrm{mRNA}$ is reduced in pituitary tumors from $\mathrm{pRb}(+/-)$ mice, suggesting that $\mathrm{p} 27^{\mathrm{Kip} 1}$ downregulation is necessary for the tumorigenicity of the pituitary even in a pRb-null background. Similarly, although p21 ${ }^{\text {Cip } 1}$-null mice do not develop pituitary tumors, this mutation cooperates with $\mathrm{pRb}$ mutation by decreasing the latency of pituitary tumors from 12 to 9 months (Brugarolas et al. 1998). Similarly, both $\mathrm{p} 27^{\mathrm{Kip} 1}$ and $\mathrm{p} 21^{\mathrm{Cip} 1}$ deficiency accelerates pituitary tumorigenesis in a $\mathrm{p} 18^{\mathrm{INK} 4 \mathrm{c}}$-null background (Franklin et al. 1998, 2000). This cooperation is dramatic in double p27 ${ }^{\mathrm{Kip} 1} ; \mathrm{p} 18^{\mathrm{INK} 4 \mathrm{c}}$ mutants, which develop pituitary adenomas within 3 months (Franklin et al. 1998).

Since both INK4 and CIP/KIP proteins are CDK inhibitors, these results suggested that these molecules cooperate in tumor suppression by strongly inactivating CDK function in the pituitary (Fig. 3). INK4 proteins specifically inhibit CDK4/6 kinases, whereas CIP/KIP proteins seem to preferentially inhibit CDK2 and CDK1. In agreement with this model, no cooperation in pituitary tumor formation is observed in double Cdk4 R24C; p18-null mice (Sotillo et al. 2005). However, the introduction of the mutated Cdk4 R24C allele in a p27-null background dramatically accelerates the development of pituitary tumors that kill these mutant mice in 8-10 weeks (Sotillo et al. 2005). No cooperation in pituitary tumor development is observed in mice mutant for Cdk4 R24C and deficient in p21 $1^{\mathrm{Cip} 1}$ (Quereda et al. 2007). However, a dramatic cooperation in pituitary tumor development is observed in mutant mice carrying a combination of the Cdk4 R24C, p21-null, and P27-null alleles (V Quereda and M Malumbres, unpublished observations). These results, together with the cooperation observed between $\mathrm{pRb}$ and $\mathrm{p} 27^{\mathrm{Kip} 1}$ (Park et al. 1999), suggest the existence of two major pathways for G1/S phase deregulation in pituitary tumors. One branch is formed 
of $\mathrm{p} 18^{\mathrm{INK} 4 \mathrm{c}} / \mathrm{CDK} 4 / \mathrm{pRB}$, whereas the other one is represented by $\mathrm{p} 27^{\mathrm{Kip} 1}$ and perhaps $\mathrm{p} 21^{\mathrm{Cip} 1}$ (Fig. 3).

The preference of CIP/KIP proteins for CDK family members other than CDK4/6 indicated that these inhibitors may target CDK2, the other interphase CDK involved in G1/S transition. However, p2 $7^{\text {Kip1 }}$ deficiency provokes similar pituitary tumors in both $\operatorname{Cdk} 2(+/+)$ and $\operatorname{Cdk} 2(-/-)$ mice (Martin et al. 2005) indicating that CDK2 is dispensible for these tumors and it is therefore not the critical target of $\mathrm{p} 27^{\mathrm{Kip} 1}$. Whether the other major cell cycle protein, $\mathrm{CDK} 1$, is the critical target of $\mathrm{p} 21^{\mathrm{Cip} 1}$ or $\mathrm{p} 27^{\mathrm{Kip} 1}$ during pituitary tumor suppression has not been fully addressed yet.

The complexity in the molecular pathways involved in pituitary tumorigenesis has recently increased after a new mouse model that suggests possible oncogenic functions of $\mathrm{p} 27^{\mathrm{Kip} 1}$. In this model, the authors designed a p27 $7^{\text {Kip1 }}$ mutant allele that does not bind cyclins and CDKs and is mostly localized to the cytoplasm (Besson et al. 2007). These knock-in mice developed more aggressive tumors than the p2 $7^{\mathrm{Kip} 1}$ null mice, and by 6 months all the animals showed aggressive pituitary tumors of the anterior lobe. This phenotype seems to be independent of the cell cycle inhibitory activity of $\mathrm{p} 27^{\mathrm{Kip} 1}$ and it may be related to the ability of $\mathrm{p} 27^{\mathrm{Kip} 1}$ to modulate stem cell function (Besson et al. 2007).

Finally, a completely new cell cycle pathway involved in pituitary oncogenesis is represented by PTTG1 (pituitary tumor transforming gene)/securin, an oncogenic molecule first identified in GH4 rat pituitary tumor cells (reviewed in Vlotides et al. (2007) and Salehi et al. (2008)). PTTG1 is involved in the mitotic checkpoint

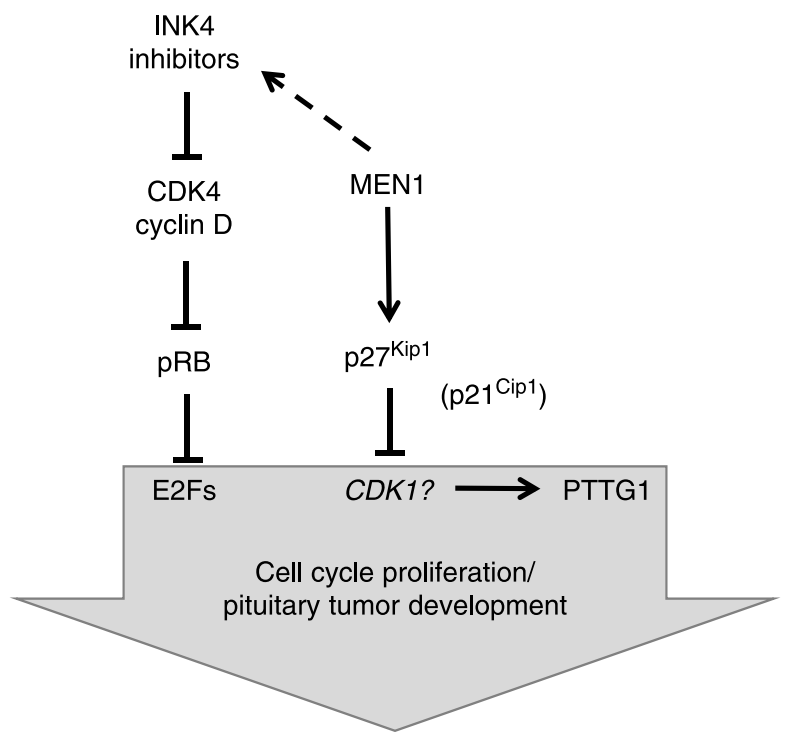

Figure 3 Major oncogenic and tumor suppressor pathways regulating the cell cycle in pituitary tumors. that prevents abnormal chromosome segregation (see below). In addition, this protein has multiple roles in cell cycle regulation at different stages (Fig. 4). The absence of this gene provokes a decrease in the incidence of pituitary tumors in $\mathrm{pRB}$ heterozygous mice, probably by triggering ARF/p53/p21-dependent senescence (Chesnokova et al. 2005, 2007). Overexpression of PTTG1 in the pituitary in transgenic mice provokes pituitary hyperplasia and focal microadenomas, and cooperates with $\mathrm{pRB}$ heterozygosity in higher incidence of tumors in the AP (Donangelo et al. 2006).

\section{Deregulation of the cell cycle in human pituitary disease}

The experimental analysis of cell cycle control in mouse models predicts that several cell cycle mutations may be present in human pituitary diseases. Pituitary tumors are common intracranial neoplasms that cause significant morbidity through mass effects and/or the inappropriate secretion of pituitary hormones. Pituitary adenomas are common intracranial neoplasms, comprising $10-15 \%$ of diagnosed brain tumors (Landis et al. 1989). Data from autopsy studies suggest that pituitary adenomas develop in $17-25 \%$ of the population (Asa \& Ezzat 2002, Ezzat et al. 2004). Approximately, 3·5-8.5\% of all pituitary tumors are diagnosed prior to the age of 20 years (Keil and Stratakis 2008). About two-thirds of pituitary tumors express and secrete pituitary hormones and produce various endocrine syndromes. Overall, prolactinomas account for about 50\% of pituitary adenomas. These adenomas cause hyperprolactinemia and subsequent problems associated to a high level of prolactin in blood (hypoestrogenism or amenorrhea in women or infertility in men). GH-producing adenomas are commonly associated with acromegaly and/or gigantism. ACTH-producing adenomas are associated with Cushing's or Nelson's syndromes (see below). TSHproducing tumors produce thyrotoxicosis, cardiac arrythmias, tremor, and weight loss. The rare gonadotroph adenomas and the major group of non-functionally or non-secreting adenomas result in hypogonadism, visual deficits, and headaches (Asa \& Ezzat 2002, Melmed 2003, Ezzat \& Asa 2006).

Several genetic and epigenetic alterations have been observed in pituitary tumorigenesis. Some classic oncogenes such as RAS or MYC are implicated in these endocrine tumors. H-RAS mutations (codon 12 $(\mathrm{Gly} \rightarrow$ Val or Arg) or 18 (Ala $\rightarrow$ Tre) ) have been reported only in pituitary carcinomas (Karga et al. 1992, Cai et al. 1994, Pei et al. 1994). c-MYC, on the other hand, is frequently overexpressed in all kind of pituitary tumors in a range between 20 and $50 \%$ depending on the type of the tumor (Woloschak et al. 1994, Wang et al. 1996). Among classic tumor-suppressor genes, p53 


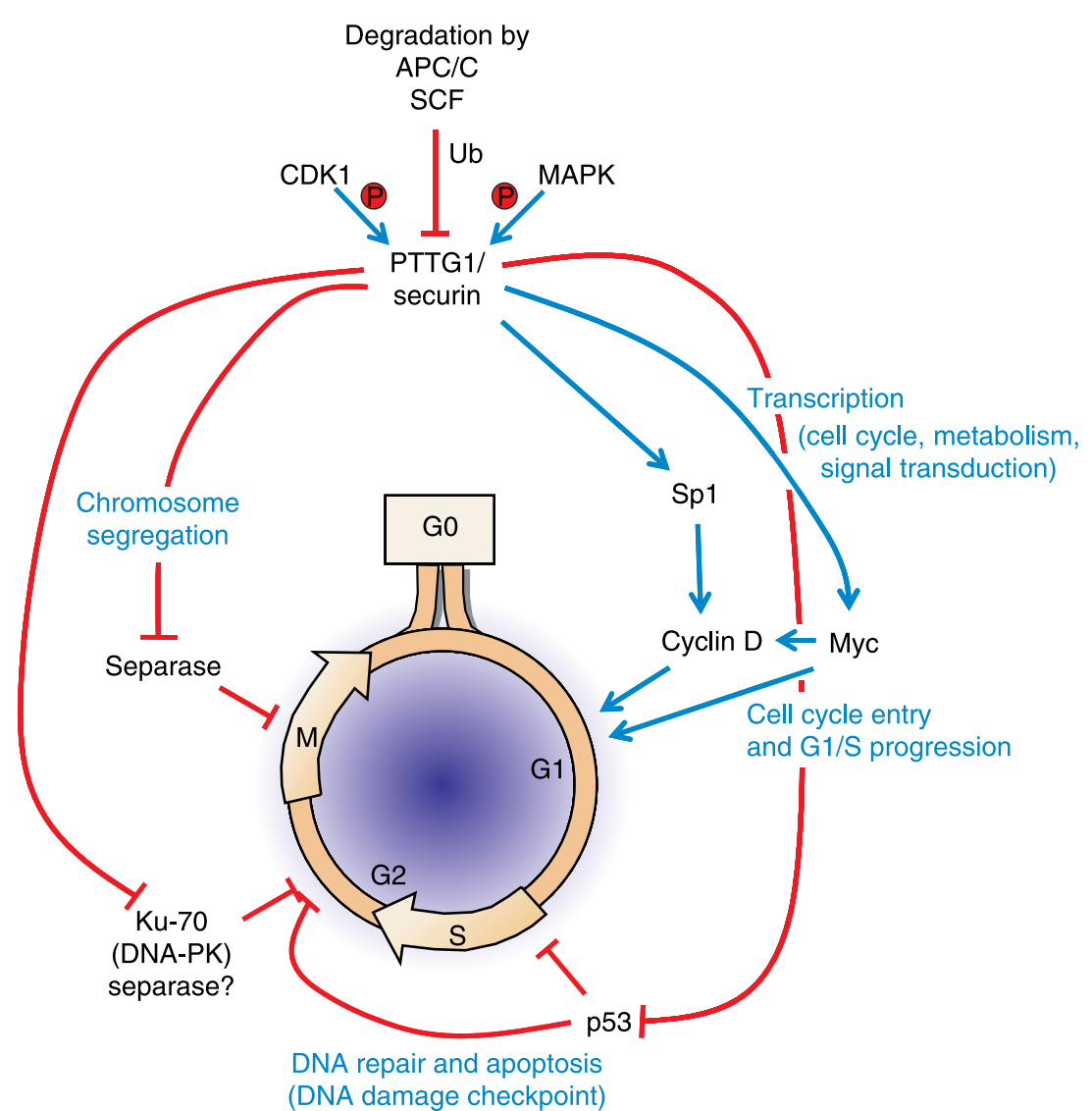

Figure 4 PTTG1/securin functions in the cell cycle (for a comprehensive review see Vlotides et al. (2007)).

accumulation (an indication of inactive p53 function) seems to be more relevant in Cushing's adenomas and invasive non-functional tumors than in non-functioning adenomas (Buckley et al. 1994, Thapar et al. 1996, Clayton et al. 1997). In addition to these classic cancer genes, a significant number of genetic or epigenetic alterations in pituitary tumors target several cell cycle regulators as described in the following paragraphs (Table 2). From these data, it has been estimated that more than $80 \%$ of pituitary tumors display alterations at least in one of the regulators of the G1/S transition of the cell cycle (Malumbres \& Barbacid 2001).

\section{Retinoblastoma protein}

Although, early studies did not find loss of pRB alleles (Cryns et al. 1993, Zhu et al. 1994), later studies found loss of heterozygosity in the human pRB gene $(R B 1)$ in malignant or highly invasive pituitary tumors (Pei et al. 1995; Table 2). Several studies based on immunodetection in tumor sections found abnormal expression of pRB in different pituitary adenomas. In some cases, decreased expression correlates with hypermethylation of the pRB promoter (Simpson et al. 2000, Ogino et al. 2005) or deletion within the protein-pocket binding domain (Simpson et al. 2000).

\section{Cyclins and cyclin-dependent kinase activity}

Cyclin D1 and D3 are often overexpressed in pituitary tumors (Jordan et al. 2000, Turner et al. 2000, Saeger et al. 2001, Simpson et al. 2001a) with some evidence of cyclin D1 allelic imbalance in one fourth of the tumor samples analyzed (Hibberts et al. 1999). In general, although cyclin D1 is overexpressed in most pituitary tumor types, this overexpresion is more relevant in non-functional tumors. Cyclin E is also deregulated in human pituitary tumors, with a significant increase in corticotroph neoplasias from patients with Cushing's disease (Jordan et al. 2000). Despite the dramatic effect of Cdk4 hyperactivation in mouse models (Table 1), no CDK4 mutations have been identified in human pituitary tumors (Simpson et al. 2001a, Honda et al. 2003, Vax et al. 2003). 
Table 2 Alteration in cell-cycle regulators in human pituitary tumors

Cancer-associated alteration (incidence)
Tumor type

Highly-invasive or malignant tumors

Somatotrophinoma and non-secreting adenomas

Pituitary adenomas

Pituitary adenomas

Invasive and non-invasive tumors

Somatotrophinomas \& non-functioning tumors

Pituitary adenomas (all different types)

Cushing's disease adenomas

Pituitary adenomas

Different pituitary tumors

Pituitary adenomas

Pituitary adenomas

Non-functioning adenomas or

Macroadenomas (all different types)

Pituitary adenomas

Pituitary adenomas

ACTH-secreting adenomas

Pituitary adenomas (all different types)

p27Kip1 (CDKN1B)

JAB1 (COPS5)

p21 ${ }^{\mathrm{CIP} 1}(C D K N 1 A)$

Securin (PTTG1)
Promoter hypermethylation (32\%)

Promoter hypermethylation (35,7\%)

Reduced expression levels

Reduced expression levels $(75 \%$ less than $10 \%$ cells-expressing in the

tumor)

Reduced expression levels (100\%)

Overexpression (100\%)

Reduced expression levels (71\%)

Overexpression (77\%)

Overexpression (92\%)

Overexpression (90\% pituitary tumors)
Corticotropes \& pituitary carcinomas Pituitary carcinomas

Non-functioning adenomas

Hormone-producing tumors

$\mathrm{GH}$-producing tumors

Pituitary adenomas (all different types)
References

Pei et al. (1995)

Simpson et al. (2000)

Yoshino et al. (2007)

Ogino et al. (2005)

Hibberts et al. (1999)

Simpson et al. $(2001 a, b)$

Saeger et al. (2001)

Jordan et al. (2000)

Nakabayashi, et al. (2001)

Woloschak et al. (1997)

Yoshino et al. (2007)

Ogino et al. (2005)

Machiavelli, et al. (2008)

Machiavelli et al. (2008)

Yoshino et al. (2007)

Ogino et al. (2005)

Morris et al. (2005)

Bamberger et al. (1999)

Lidhar et al. (1999)

Korbonits et al. (2002)

Neto, et al. (2005)

Neto et al. (2005)

Neto et al. (2005)

Zhang et al. (1999)

\section{INK4 inhibitors}

Although point mutations in INK4 inhibitors are not frequent in human pituitary adenomas, the expression of $\mathrm{p} 16^{\mathrm{INK} 4 \mathrm{a}}$ and $\mathrm{p} 15^{\mathrm{INK} 4 \mathrm{~b}}$ is often silenced. Silencing of the $\mathrm{p} 16^{\mathrm{INK} 4 \mathrm{a}}$ gene $(C D K N 2 A)$ by hypermethylation was first reported in the late 90s (Woloschak et al. 1997). A detailed analysis suggested that CDKN2A methylation was confined to particular adenoma subtypes (Simpson et al. 1999) and these findings were subsequently confirmed by several other groups concluding that hypermethylation of the $C D K N 2 A$ is the most common epigenetic deregulation in these neoplasias (Morris et al. 2005, Ogino et al. 2005, Yoshino et al. 2007). $\mathrm{p} 16^{\mathrm{INK} 4 \mathrm{a}}$ is able to inhibit cell proliferation in pituitary tumor cells in correlation with a shift in the phosphorylation status of $\mathrm{pRB}$, suggesting the relevance of this CDK inhibitor in the activation of $\mathrm{pRB}$ and pituitary tumor suppression (Frost et al. 1999).

\section{CIP/KIP inhibitors}

Soon after the publication of the phenotype of p27 $7^{\text {Kip1 }}$. deficient mice, several studies interrogated the alteration of this inhibitor in human tumors. Early studies detected no p27 $7^{\text {Kip } 1}$ mutations in human pituitary tumors (Tanaka et al. 1997, Dahia et al. 1998). The fact that $\mathrm{p} 27^{\mathrm{Kip} 1}$ is haploinsufficient for tumor suppression (Fero et al. 1998), however, suggests that decreased expression may be relevant in tumor development. In fact, downregulation of $\mathrm{p} 27^{\mathrm{Kip} 1}$ protein expression is commonly observed in pituitary carcinomas and corticotroph adenomas, and recurrent human pituitary adenomas show lower $\mathrm{p} 27^{\mathrm{Kip} 1}$ protein levels than non-recurrent adenomas (Bamberger et al. 1999, Lidhar et al. 1999). p27 $7^{\text {Kip1 }}$ mRNA levels are not generally decreased in tumors suggesting increased proteolysis of this cell cycle inhibitor in cancer (Bloom \& Pagano 2003). Ubiquitin-mediated degradation of $\mathrm{p} 27^{\mathrm{Kip} 1}$ is controlled by SKP2, an F-box protein with diverse oncogenic functions (Frescas \& Pagano 2008). Whether SKP2 is the relevant F-box protein for degradation of $\mathrm{p} 27^{\mathrm{Kip} 1}$ in pituitary tumors is not yet clear (Musat et al. 2002). Degradation of p27 $7^{\mathrm{Kip} 1}$ may also be induced by JAB1 (JUN activation domainbinding protein), a transcriptional cofactor for AP-1 (Chamovitz \& Segal 2001). In addition to this function, $\mathrm{JAB} 1$ is able to translocate phosphorylated $\mathrm{p} 27^{\mathrm{Kip} 1}$ to 
the cytoplasm for protein degradation by the proteasome. Some pituitary carcinomas display a small but significant increase in JAB1 levels possibly resulting in increased $\mathrm{p} 27^{\mathrm{Kip} 1}$ degradation (Korbonits et al. 2002). Although, genetic alterations in $\mathrm{p} 21^{\mathrm{Cip} 1}$ are not commonly observed, this inhibitor may also be downregulated through epigenetic modifications in pituitary neoplasias (Yoshino et al. 2007, Zhu et al. 2008).

Although, the majority of pituitary tumors in humans are spontaneous, in some cases they are part of genetic syndromes predisposing to pituitary and other tumors. These inherited syndromes include multiple endocrine neoplasia (MEN)-1, carney complex, familial isolated pituitary adenomas, and the Cushing's and Nelson's syndromes (Melmed 2003, Beckers \& Daly 2007, Keil \& Stratakis 2008). The MEN-1 syndrome is characterized by predisposition to pituitary adenomas, parathyroid hyperplasia, and pancreatic endocrine tumors. Pituitary adenomas affect between 25 and $30 \%$ of MEN-1 patients (Burgess et al. 1998). These patients display germ line mutations in the MEN1 gene, which increase the susceptibility to all major pituitary adenoma subtypes. MEN1 has been described as a direct regulator of $\mathrm{p} 27^{\mathrm{Kip} 1}$ and $\mathrm{p} 18^{\mathrm{INK} 4 \mathrm{c}}$ (Karnik et al. 2005, Milne et al. 2005), and loss of function of MEN1 results in down-regulation of these two inhibitors with the subsequent deregulation in cell proliferation. In recent mouse models, Men1 mutations cooperate with p18 ${ }^{\mathrm{INK} 4 \mathrm{c}}$ but not $\mathrm{p} 27^{\mathrm{Kip} 1}$ inactivation (Bai et al. 2007) suggesting that the MEN1 protein is mostly acting upstream of $\mathrm{p} 27^{\mathrm{Kip} 1}$ (Fig. 3). Recently, a mutation in $C D K N 1 B$, the rat gene encoding $\mathrm{p} 27^{\mathrm{Kip} 1}$, has been reported to be associated with a MEN-1-like syndrome in a murine model (Pellegata et al. 2006). A germ line nonsense mutation in the human CDKN1B gene was also identified in a MEN1 mutation-negative patient presenting with pituitary and parathyroid tumors. Expanded pedigree analysis showed that the p27 $7^{\mathrm{Kip} 1}$ mutation was associated with the development of an MEN-1-like phenotype in multiple generations (Pellegata et al. 2006).

\section{PTTG1/securin}

PTTG1 was initially identified through a differential display analysis of gene expression in rat pituitary tumor cells (Pei \& Melmed 1997). PTTG1, also known as securin, is an inactivating partner of separase, the major effector for chromosome segregation during mitosis (Zou et al. 1999). PTTG1 is overexpressed in more than $90 \%$ of all type of pituitary tumors (Zhang et al. 1999). In addition, this protein is frequently overexpressed in metastatic or genomically instable tumors, suggesting a relevant role for securin in tumor progression (Perez de Castro et al. 2007). Securin is regulated by CDK1-mediated phosphorylation (Holt et al. 2008) suggesting a link between the control of the cell cycle by CDKs and PTTG1 function (Fig. 3). Despite the frequent deregulation of PTTG1 in pituitary and other tumors, it is not clear yet whether its oncogenic role is mediated by its mitotic functions or the ability of PTTG1 or modulate DNA repair or Sp1-mediated transcription (Vlotides et al. 2007; Fig. 4).

\section{Future perspectives and therapeutic implications in pituitary disease}

The implication of cell cycle deregulation in pituitary tumorigenesis is well established from experimental data in mouse models (Table 1) and the molecular pathology of human tumors (Table 2). Most cell cycle mutations affect regulators of the $\mathrm{Gl} / \mathrm{S}$ transition in the cell cycle, including the CDK4/pRB pathway and cell cycle inhibitors such as p27 ${ }^{\text {Kip1 }}$ (Malumbres \& Barbacid 2001). The role of the pioneer pituitary tumor oncogene PTTG1 is not clear at present, although it may participate in tumor development at different levels. Overall, these mutations provoke a hyperactive cell cycle that ensures unscheduled proliferation and genomic instability in pituitary tumors.

On the other hand, defective cell cycle function also affects pituitary homeostasis. Cdk4 deficient mice are smaller than wild-type littermates and display partial sterility (Rane et al. 1999). These phenotypes are linked to hypomorphic pituitaries with a significant decrease in hormone-producing cells. In particular, Cdk4 is required for post-natal proliferation of somato/lactotrophs of the pituitary (Moons et al. 2002, Jirawatnotai et al. 2004). Some recent results suggest that Cdk4 may also modulate cell proliferation in specific pituitary progenitor cells (Macias et al. 2008). Re-expression of Cdk4 in the pituitary rescues the sterility indicating that this defect is secondary to the defects in hormoneexpressing cells in the pituitary (Martin et al. 2003). However, that re-expression of Cdk4 in the pituitary does not rescue the smaller size of Cdk4-null mice suggesting that dwarfism in these animals is not due to pituitary dysfunction (Martin et al. 2003).

Pttg1-deficient mice also display pituitary hypoplasia and decreased proliferation of pancreatic $\beta$-cells (Melmed 2003, Vlotides et al. 2007). The similarity between Cdk4 and Pttg1 deficiency is striking, although the molecular reasons are unclear. To what extent these cell cycle control pathways contribute to pituitary development and homeostasis is not fully understood yet. However, these experimental results may suggest a relevant relationship between cell cycle regulators and the ability of the pituitary to develop and to respond to physiological stresses. Given the relevance of cell cycle regulators in the correct function of stem cells (Janzen et al. 2006, Jablonska et al. 2007, Pei et al. 2007, Macias 
et al. 2008), it is tempting to speculate on the relevance of the cell cycle in pituitary stem cell self-renewal and its implications in pituitary syndromes and tumors.

The observed deregulation of the cell cycle in pituitary disease has important consequences in the treatment of these pathologies. Current treatments in pituitary tumors target neuroendocrine receptors to block hormone-receptor signaling through different pathways (Heaney \& Melmed 2004). Currently used drugs include dopamine-receptor agonists and somatostatin analogues. These substances are used to suppress excess hormone secretion and proliferation of pituitary cells, although they also produce several side effects (Heaney \& Melmed 2004). The frequent overexpression of cyclins and inactivation of cell cycle inhibitors such as INK4 proteins suggests that CDK hyperactivation is a common theme in pituitary neoplasias. Several small molecular CDK inhibitors are now being evaluated for cancer therapy in many different tumor types (Malumbres et al. 2008, Perez de Castro et al. 2008). Although, these drugs have not been clinically tested in pituitary tumors, pre-clinical studies suggest that CDK inhibitors may be effective for treating pituitary diseases, at least in individuals with cell cycle mutations that specifically affect this pathway (Sotillo et al. 2005). A better knowledge of the specific genetic and epigenetic alterations in human patients will be necessary to select the right combination of current treatments or to propose new therapeutic approaches. Current and future genetic models in the mouse will help us to understand the development of pituitary disorders and to evaluate these therapies before their use in the Clinic.

\section{Declaration of interest}

The authors declare that there is no conflict of interest that could be perceived as prejudicing the impartiality of the research reported.

\section{Funding}

V Quereda is supported by a fellowship from the Spanish Ministerio de Educación y Ciencia (MEC). The Cell Division and Cancer Group of the CNIO is supported by grants from the Foundation Mutua Madrileña Automovilista, MEC (SAF2006-05186), Association International for Cancer Research (AICR \#08-0188), Comunidad de Madrid (S-BIO-0283-2006), and the Consolider-Ingenio 2010 (CSD2007-00017) Programme from the MEC.

\section{Acknowledgements}

We thank members of the Cell Division and Cancer Group of the CNIO for comments and helpful discussions.

\section{References}

Asa SL \& Ezzat S 2002 The pathogenesis of pituitary tumours. Nature Reviews Cancer 2 836-849.

Bai F, Pei XH, Nishikawa T, Smith MD \& Xiong Y 2007 Yp18Ink4c, but not $\mathrm{p} 27^{\mathrm{Kip} 1}$, collaborates with Men 1 to suppress neuroendocrine organ tumors. Molecular and Cellular Biology 27 1495-1504.

Bamberger CM, Fehn M, Bamberger AM, Ludecke DK, Beil FU, Saeger W \& Schulte HM 1999 Reduced expression levels of the cell cycle inhibitor p2 $7^{\mathrm{Kip} 1}$ in human pituitary adenomas. European Journal of Endocrinology 140 250-255.

Beckers A \& Daly AF 2007 The clinical, pathological, and genetic features of familial isolated pituitary adenomas. European Journal of Endocrinology 157 371-382.

Besson A, Hwang HC, Cicero S, Donovan SL, Gurian-West M, Johnson D, Clurman BE, Dyer MA \& Roberts JM 2007 Discovery of an oncogenic activity in p $27^{\text {Kip } 1}$ that causes stem cell expansion and a multiple tumor phenotype. Genes and Development 21 1731-1746.

Bloom J \& Pagano M 2003 Deregulated degradation of the CDK inhibitor p27 and malignant transformation. Seminars in Cancer Biology 13 41-47.

Brugarolas J, Bronson RT \& Jacks T 1998 p21 is a critical CDK2 regulator essential for proliferation control in Rb-deficient cells. Journal of Cell Biology 141 503-514.

Buckley N, Bates AS, Broome JC, Strange RC, Perrett CW, Burke CW \& Clayton RN 1994 p53 Protein accumulates in Cushings adenomas and invasive non-functional adenomas. Journal of Clinical Endocrinology and Metabolism 79 1513-1516.

Burgess JR, Greenaway TM \& Shepherd JJ 1998 Expression of the MEN-1 gene in a large kindred with multiple endocrine neoplasia type 1. Journal of Internal Medicine 243 465-470.

Cai WY, Alexander JM, Hedley-Whyte ET, Scheithauer BW, Jameson JL, Zervas NT \& Klibanski A 1994 Ras mutations in human prolactinomas and pituitary carcinomas. Journal of Clinical Endocrinology and Metabolism 78 89-93.

Chamovitz DA \& Segal D 2001 JAB1/CSN5 and the COP9 signalosome. A complex situation. EMBO Reports 2 96-101.

Chen J, Hersmus N, Van Duppen V, Caesens P, Denef C \& Vankelecom H 2005 The adult pituitary contains a cell population displaying stem/progenitor cell and early embryonic characteristics. Endocrinology 146 3985-3998.

Chesnokova V, Kovacs K, Castro AV, Zonis S \& Melmed S 2005 Pituitary hypoplasia in $\mathrm{Pttg}-/-$ mice is protective for $\mathrm{Rb}+/-$ pituitary tumorigenesis. Molecular Endocrinology 19 2371-2379.

Chesnokova V, Zonis S, Rubinek T, Yu R, Ben-Shlomo A, Kovacs K, Wawrowsky K \& Melmed S 2007 Senescence mediates pituitary hypoplasia and restrains pituitary tumor growth. Cancer Research 67 10564-10572.

Chien WM, Garrison K, Caufield E, Orthel J, Dill J \& Fero ML 2007 Differential gene expression of $\mathrm{p} 27^{\mathrm{Kip} 1}$ and $\mathrm{Rb}$ knockout pituitary tumors associated with altered growth and angiogenesis. Cell Cycle 6 $750-757$.

Clarke AR, Maandag ER, van Roon M, van der Lugt NM, van der Valk M, Hooper ML, Berns A \& te Riele H 1992 Requirement for a functional Rb-1 gene in murine development. Nature $\mathbf{3 5 9}$ 328-330.

Clayton RN, Boggild M, Bates AS, Bicknell J, Simpson D \& Farrell W 1997 Tumour suppressor genes in the pathogenesis of human pituitary tumours. Hormone Research 47 185-193.

Cryns VL, Alexander JM, Klibanski A \& Arnold A 1993 The retinoblastoma gene in human pituitary tumors. Journal of Clinical Endocrinology and Metabolism 77 644-646.

Dahia PL, Aguiar RC, Honegger J, Fahlbush R, Jordan S, Lowe DG, Lu X, Clayton RN, Besser GM \& Grossman AB 1998 Mutation and expression analysis of the p27/kipl gene in corticotrophinsecreting tumours. Oncogene 16 69-76. 
Donangelo I, Gutman S, Horvath E, Kovacs K, Wawrowsky K, Mount M \& Melmed S 2006 Pituitary tumor transforming gene overexpression facilitates pituitary tumor development. Endocrinology 147 4781-4791.

Ezzat S \& Asa SL 2006 Mechanisms of disease: The pathogenesis of pituitary tumors. Nature Clinical Practice Endocrinology and Metabolism 2 220-230

Ezzat S, Asa SL, Couldwell WT, Barr CE, Dodge WE, Vance ML \& McCutcheon IE 2004 The prevalence of pituitary adenomas: a systematic review. Cancer 101 613-619.

Fauquier T, Rizzoti K, Dattani M, Lovell-Badge R \& Robinson IC 2008 SOX2 expressing progenitor cells generate all the major cell types in the adult mouse pituitary gland. Proceedings National Academy of Sciences USA 105 2907-2912.

Fero ML, Rivkin M, Tasch M, Porter P, Carow CE, Firpo E, Polyak K, Tsai LH, Broudy V, Perlmutter RM et al. 1996 A syndrome of multiorgan hyperplasia with features of gigantism, tumorigenesis, and female sterility in p27 $\left({ }^{\mathrm{Kip} 1}{ }^{1}\right.$-deficient mice. Cell 85 733-744.

Fero ML, Randel E, Gurley KE, Roberts JM \& Kemp CJ 1998 The murine gene $\mathrm{p} 27^{\mathrm{Kip} 1}$ is haplo-insufficient for tumour suppression. Nature 396 177-180.

Franklin DS, Godfrey VL, Lee H, Kovalev GI, Schoonhoven R, Chen-Kiang S, Su L \& Xiong Y 1998 CDK inhibitors p18(INK4c) and p27( ${ }^{\text {Kip }}{ }^{1}$ ) mediate two separate pathways to collaboratively suppress pituitary tumorigenesis. Genes and Development 122899 2911.

Franklin DS, Godfrey VL, O'Brien DA, Deng C \& Xiong Y 2000 Functional collaboration between different cyclin-dependent kinase inhibitors suppresses tumor growth with distinct tissue specificity. Molecular and Cellular Biology 20 6147-6158.

Frescas D \& Pagano M 2008 Deregulated proteolysis by the F-box proteins SKP2 and beta-TrCP: tipping the scales of cancer. Nature Reviews Cancer 8 438-449.

Frost SJ, Simpson DJ, Clayton RN \& Farrell WE 1999 Transfection of an inducible p16/CDKN2A construct mediates reversible growth inhibition and G1 arrest in the AtT20 pituitary tumor cell line. Molecular Endocrinology 13 1801-1810.

Garcia-Lavandeira M, Quereda V, Flores I, Saez C, Diaz-Rodriguez E, Japon MA, Ryan AK, Blasco MA, Dieguez C, Malumbres M et al. 2008 A GRFa2/Prop1/Stem (GPS) Cell Niche in the Pituitary. PLoS One In Press.

Gleiberman AS, Michurina T, Encinas JM, RoigJL, Krasnov P, Balordi F, Fishell G, Rosenfeld MG \& Enikolopov G 2008 Genetic approaches identify adult pituitary stem cells. PNAS 105 6332-6337.

Heaney AP \& Melmed S 2004 Molecular targets in pituitary tumours. Nature Reviews Cancer 4 285-295.

Hibberts NA, Simpson DJ, Bicknell JE, Broome JC, Hoban PR, Clayton RN \& Farrell WE 1999 Analysis of cyclin D1 (CCND1) allelic imbalance and overexpression in sporadic human pituitary tumors. Clinical Cancer Reearch 5 2133-2139.

Holt LJ, Krutchinsky AN \& Morgan DO 2008 Positive feedback sharpens the anaphase switch. Nature 454 353-357.

Honda S, Tanaka-Kosugi C, Yamada S, Sano T, Matsumoto T, Itakura M \& Yoshimoto K 2003 Human pituitary adenomas infrequently contain inactivation of retinoblastoma 1 gene and activation of cyclin dependent kinase 4 gene. Endocrinology Journal 50 309-318.

Jablonska B, Aguirre A, Vandenbosch R, Belachew S, Berthet C, Kaldis P \& Gallo V 2007 CDK2 is critical for proliferation and self-renewal of neural progenitor cells in the adult subventricular zone. Journal of Cell Biology 179 1231-1245.

Jacks T, Fazeli A, Schmitt EM, Bronson RT, Goodell MA \& Weinberg RA 1992 Effects of an Rb mutation in the mouse. Nature 359 295-300.

Janzen V, Forkert R, Fleming HE, Saito Y, Waring MT, Dombkowski DM, Cheng T, DePinho RA, Sharpless NE \& Scadden DT 2006 Stem-cell ageing modified by the cyclin-dependent kinase inhibitor p16INK4a. Nature 443 421-426.
Jirawatnotai S, Aziyu A, Osmundson EC, Moons DS, Zou X, Kineman RD \& Kiyokawa H 2004 CDK4 is indispensable for postnatal proliferation of the anterior pituitary. Journal of Biological Chemistry $27951100-51106$.

Jordan S, Lidhar K, Korbonits M, Lowe DG \& Grossman AB 2000 Cyclin D and cyclin E expression in normal and adenomatous pituitary. European Journal of Endocrinology 143 R1-R6.

Karga HJ, Alexander JM, Hedley-Whyte ET, Klibanski A \& Jameson JL 1992 Ras mutations in human pituitary tumors. Journal of Clinical Endocrinology and Metabolism 74 914-919.

Karnik SK, Hughes CM, Gu X, Rozenblatt-Rosen O, McLean GW, Xiong Y, Meyerson M \& Kim SK 2005 Menin regulates pancreatic islet growth by promoting histone methylation and expression of genes encoding p27 $7^{\mathrm{Kip} 1}$ and p18INK4c. PNAS 102 14659-14664.

Keil MF \& Stratakis CA 2008 Pituitary tumors in childhood: update of diagnosis, treatment and molecular genetics. Expert Reviews in Neurotherapy 8 563-574.

Kiyokawa H, Kineman RD, Manova-Todorova KO, Soares VC, Hoffman ES, Ono M, Khanam D, Hayday AC, Frohman LA \& Koff A 1996 Enhanced growth of mice lacking the cyclin-dependent kinase inhibitor function of p27 $\left({ }^{\mathrm{Kip} 1}\right)$. Cell 85 721-732.

Korbonits M, Chahal HS, Kaltsas G, Jordan S, Urmanova Y, Khalimova Z, Harris PE, Farrell WE, Claret FX \& Grossman AB 2002 Expression of phosphorylated p27 $\left({ }^{\text {Kip1 }}\right)$ protein and Jun activation domainbinding protein 1 in human pituitary tumors. Journal of Clinical Endocrinology and Metabolism 87 2635-2643.

Landis CA, Masters SB, Spada A, Pace AM, Bourne HR \& Vallar L 1989 GTPase inhibiting mutations activate the alpha chain of Gs and stimulate adenylyl cyclase in human pituitary tumours. Nature $\mathbf{3 4 0}$ 692-696.

Latres E, Malumbres M, Sotillo R, Martin J, Ortega S, Martin-Caballero J, Flores JM, Cordon-Cardo C \& Barbacid M 2000 Limited overlapping roles of P15(INK4b) and P18(INK4c) cell cycle inhibitors in proliferation and tumorigenesis. EMBO Journal 19 3496-3506.

Lazzerini Denchi E, Attwooll C, Pasini D \& Helin K 2005 Deregulated E2F activity induces hyperplasia and senescence-like features in the mouse pituitary gland. Molecular and Cellular Biology 25 2660-2672.

Lee EY, Chang CY, Hu N, Wang YC, Lai CC, Herrup K, Lee WH \& Bradley A 1992 Mice deficient for $\mathrm{Rb}$ are nonviable and show defects in neurogenesis and haematopoiesis. Nature 359 288-294.

Lee EY, Cam H, Ziebold U, Rayman JB, Lees JA \& Dynlacht BD 2002 E2F4, loss suppresses tumorigenesis in $\mathrm{Rb}$ mutant mice. Cancer Cell $2463-472$.

Lepore DA, Roeszler K, Wagner J, Ross SA, Bauer K \& Thomas PQ 2005 Identification and enrichment of colony-forming cells from the adult murine pituitary. Experimental Cell Research 308 166-176.

Leung SW, Wloga EH, Castro AF, Nguyen T, Bronson RT \& Yamasaki L 2004 A dynamic switch in $\mathrm{Rb}+/-$ mediated neuroendocrine tumorigenesis. Oncogene 23 3296-3307.

Lidhar K, Korbonits M, Jordan S, Khalimova Z, Kaltsas G, Lu X, Clayton RN, Jenkins PJ, Monson JP, Besser GM et al. 1999 Low expression of the cell cycle inhibitor p27 $7^{\mathrm{Kip} 1}$ in normal corticotroph cells, corticotroph tumors, and malignant pituitary tumors. Journal of Clinical Endocrinology and Metabolism 84 3823-3830.

Machiavelli G, Cotignola J, Danilowicz K, Carbonara C, Paes de Lima A, Basso A, Bruno OD \& Szijan I 2008 Expression of p16(INK4A) gene in human pituitary tumours. Pituitary 11 71-75.

Macias E, de Marval PL, Senderowicz A, Cullen J \& Rodriguez-Puebla ML 2008 Expression of CDK4 or CDK2 in mouse oral cavity is retained in adult pituitary with distinct effects on tumorigenesis. Cancer Research 68 162-171.

Malumbres M \& Barbacid M 2001 To cycle or not to cycle: a critical decision in cancer. Nature Reviews Cancer 1 222-231.

Malumbres M \& Barbacid M 2005 Mammalian cyclin-dependent kinases. Trends in Biochemical Sciences 30 630-641. 
Malumbres M, Pevarello P, Barbacid M \& Bischoff JR 2008 CDK, inhibitors in cancer therapy: what is next? Trends in Pharmacological Sciences 29 16-21.

Martin J, Hunt SL, Dubus P, Sotillo R, Nehme-Pelluard F, Magnuson MA, Parlow AF, Malumbres M, Ortega S \& Barbacid M 2003 Genetic rescue of CDK4 null mice restores pancreatic beta-cell proliferation but not homeostatic cell number. Oncogene 22 5261-5269.

Martin A, Odajima J, Hunt SL, Dubus P, Ortega S \& Malumbres M 2005 CDK2 is dispensable for cell cycle inhibition and tumor suppression mediated by p27 $\left({ }^{\text {Kip1 }}\right)$ and p21(Cip1). Cancer Cell 7 591-598.

Matsunaga $\mathrm{E} 1980$ On estimating penetrance of the retinoblastoma gene. Human 56 127-128.

Melmed S 2003 Mechanisms for pituitary tumorigenesis: the plastic pituitary. Journal of Clinical Investigation 112 1603-1618.

Milne TA, Hughes CM, Lloyd R, Yang Z, Rozenblatt-Rosen O, Dou Y, Schnepp RW, Krankel C, Livolsi VA, Gibbs D et al. 2005 Menin and MLL cooperatively regulate expression of cyclin-dependent kinase inhibitors. PNAS 102 749-754.

Moons DS, Jirawatnotai S, Parlow AF, Gibori G, Kineman RD \& Kiyokawa H 2002 Pituitary hypoplasia and lactotroph dysfunction in mice deficient for cyclin-dependent kinase-4. Endocrinology 143 3001-3008.

Morris DG, Musat M, Czirjak S, Hanzely Z, Lillington DM, Korbonits M \& Grossman AB 2005 Differential gene expression in pituitary adenomas by oligonucleotide array analysis. European Journal of Endocrinology 153 143-151.

Musat M, Korbonits M, Pyle M, Gueorguiev M, Kola B, Morris DG, Powell M, Dumitrache C, Poiana C \& Grossman AB 2002 The expression of the F-box protein Skp2 is negatively associated with p27 expression in human pituitary tumors. Pituitary $\mathbf{5}$ 235-242.

Nakabayashi H, Sunada I \& Hara M 2001 Immunohistochemical analyses of cell cycle-related proteins, apoptosis, and proliferation in pituitary adenomas. Journal of Histochemistry and Cytochemistry $\mathbf{4 9}$ 1193-1194.

Nakayama K, Ishida N, Shirane M, Inomata A, Inoue T, Shishido N, Horii I, Loh DY \& Nakayama K 1996 Mice lacking p27( ${ }^{\text {Kip1}}$ ) display increased body size, multiple organ hyperplasia, retinal dysplasia, and pituitary tumors. Cell 85 707-720.

Neto AG, McCutcheon IE, Vang R, Spencer ML, Zhang W \& Fuller GN 2005 Elevated expression of $\mathrm{p} 21$ (WAF1/Cip1) in hormonally active pituitary adenomas. Annual Diagnostic Pathology 9 6-10.

Ogino A, Yoshino A, Katayama Y, Watanabe T, Ota T, Komine C, Yokoyama T \& Fukushima T 2005 The p15(INK4b)/p16(INK4a)/RB1 pathway is frequently deregulated in human pituitary adenomas. Journal of Neuropathology and Experimental Neurology 64 398-403.

Park MS, Rosai J, Nguyen HT, Capodieci P, Cordon-Cardo C \& Koff A 1999 p27 and $\mathrm{Rb}$ are on overlapping pathways suppressing tumorigenesis in mice. PNAS 96 6382-6387.

Pei L \& Melmed S 1997 Isolation and characterization of a pituitary tumor-transforming gene (PTTG). Molecular Endocrinology 11 433-441.

Pei L, Melmed S, Scheithauer B, Kovacs K \& Prager D 1994 H-ras mutations in human pituitary carcinoma metastases. Journal of Clinical Endocrinology and Metabolism 78 842-846.

Pei L, Melmed S, Scheithauer B, Kovacs K, Benedict WF \& Prager D 1995 Frequent loss of heterozygosity at the retinoblastoma susceptibility gene (RB) locus in aggressive pituitary tumors: evidence for a chromosome 13 tumor suppressor gene other than RB. Cancer Research 55 1613-1616.

Pei XH, Bai F, Smith MD \& Xiong Y 2007 p18Ink4c collaborates with Men 1 to constrain lung stem cell expansion and suppress nonsmall-cell lung cancers. Cancer Research 67 3162-3170.

Pellegata NS, Quintanilla-Martinez L, Siggelkow H, Samson E, Bink K, Hofler H, Fend F, Graw J \& Atkinson MJ 2006 Germ-line mutations in $\mathrm{p} 27^{\mathrm{Kip} 1}$ cause a multiple endocrine neoplasia syndrome in rats and humans. PNAS 103 15558-15563.
Perez de Castro I, de Carcer G \& Malumbres M 2007 A census of mitotic cancer genes: new insights into tumor cell biology and cancer therapy. Carcinogenesis 28 899-912.

Perez de Castro I, de Carcer G, Montoya G \& Malumbres M 2008 Emerging cancer therapeutic opportunities by inhibiting mitotic kinases. Current Opinion in Pharmacology 8 375-383.

Quereda V, Martinalbo J, Dubus P, Carnero A \& Malumbres M 2007 Genetic cooperation between p21Cip1 and INK4 inhibitors in cellular senescence and tumor suppression. Oncogene 26 7665-7674.

Ramsey MR, Krishnamurthy J, Pei XH, Torrice C, Lin W, Carrasco DR, Ligon KL, Xiong Y \& Sharpless NE 2007 Expression of p16Ink4a compensates for p18Ink4c loss in cyclin-dependent kinase 4/6dependent tumors and tissues. Cancer Research 67 4732-4741.

Rane SG, Dubus P, Mettus RV, Galbreath EJ, Boden G, Reddy EP \& Barbacid M 1999 Loss of CDK4 expression causes insulin-deficient diabetes and CDK4 activation results in beta-islet cell hyperplasia. Nature Genetics 22 44-52.

Rane SG, Cosenza SC, Mettus RV \& Reddy EP 2002 Germ line transmission of the CDK4(R24C) mutation facilitates tumorigenesis and escape from cellular senescence. Molecular and Cellular Biology 22 644-656.

Saeger W, Schreiber S \& Ludecke DK 2001 Cyclins D1 and D3 and topoisomerase II alpha in inactive pituitary adenomas. Endocrine Pathology 12 39-47.

Salehi F, Kovacs K, Scheithauer BW, Lloyd RV \& Cusimano M 2008 Pituitary tumor-transforming gene in endocrine and other neoplasms: a review and update. Endocrine-Related Cancer 15 721-743.

Simpson DJ, Bicknell JE, McNicol AM, Clayton RN \& Farrell WE 1999 Hypermethylation of the p16/CDKN2A/MTSI gene and loss of protein expression is associated with nonfunctional pituitary adenomas but not somatotrophinomas. Genes Chromosomes and Cancer 24 328-336.

Simpson DJ, Hibberts NA, McNicol AM, Clayton RN \& Farrell WE 2000 Loss of pRB expression in pituitary adenomas is associated with methylation of the RB1 CpG island. Cancer Research 60 1211-1216.

Simpson DJ, Frost SJ, Bicknell JE, Broome JC, McNicol AM, Clayton RN \& Farrell WE $2001 a$ Aberrant expression of G(1)/S regulators is a frequent event in sporadic pituitary adenomas. Carcinogenesis 22 $1149-1154$

Simpson DJ, Fryer AA, Grossman AB, Wass JA, Pfeifer M, Kros JM, Clayton RN \& Farrell WE $2001 b$ Cyclin D1 (CCND1) genotype is associated with tumour grade in sporadic pituitary adenomas. Carcinogenesis 22 1801-1807.

Sotillo R, Dubus P, Martin J, de la Cueva E, Ortega S, Malumbres M \& Barbacid M 2001 Wide spectrum of tumors in knock-in mice carrying a CDK4 protein insensitive to INK4 inhibitors. EMBO Journal 20 6637-6647.

Sotillo R, Renner O, Dubus P, Ruiz-Cabello J, Martin-Caballero J, Barbacid M, Carnero A \& Malumbres M 2005 Cooperation between CDK4 and p27kip1 in tumor development: a preclinical model to evaluate cell cycle inhibitors with therapeutic activity. Cancer Research 65 3846-3852.

Tanaka C, Yoshimoto K, Yang P, Kimura T, Yamada S, Moritani M, Sano T \& Itakura M 1997 Infrequent mutations of p27 ${ }^{\text {Kip } 1}$ gene and trisomy 12 in a subset of human pituitary adenomas. Journal of Clinical Endocrinology and Metabolism 82 3141-3147.

Thapar K, Scheithauer BW, Kovacs K, Pernicone PJ \& Laws ER Jr 1996 p53 Expression in pituitary adenomas and carcinomas: correlation with invasiveness and tumor growth fractions. Neurosurgery 38 765-770.

Turner HE, Nagy Z, Sullivan N, Esiri MM \& Wass JA 2000 Expression analysis of cyclins in pituitary adenomas and the normal pituitary gland. Clinical Endocrinology (Oxf) 53 337-344.

Vankelecom H 2007 Non-hormonal cell types in the pituitary candidating for stem cell. Seminars in Cell Developmental Biology 18 $559-570$. 
Vax VV, Bibi R, Diaz-Cano S, Gueorguiev M, Kola B, Borboli N, Bressacde Paillerets B, Walker GJ, Dedov II, Grossman AB et al. 2003 Activating point mutations in cyclin-dependent kinase 4 are not seen in sporadic pituitary adenomas, insulinomas or Leydig cell tumours. Journal of Endocrinology 178 301-310.

Vlotides G, Eigler T \& Melmed S 2007 Pituitary tumor-transforming gene: physiology and implications for tumorigenesis. Endocrine Reviews 28 165-186.

Wang DG, Johnston CF, Atkinson AB, Heaney AP, Mirakhur M \& Buchanan KD 1996 Expression of bcl-2 oncoprotein in pituitary tumours: comparison with c-myc. Journal of Clinical Pathology 49 795-797.

Woloschak M, Roberts JL \& Post K 1994 c-myc, c-fos, and c-myb gene expression in human pituitary adenomas. Journal of Clinical Endocrinology and Metabolism 79 253-257.

Woloschak M, Yu A \& Post KD 1997 Frequent inactivation of the p16 gene in human pituitary tumors by gene methylation. Molecular Carcinogenesis 19 221-224.

Yamasaki L, Bronson R, Williams BO, Dyson NJ, Harlow E \& Jacks T 1998 Loss of E2F-1 reduces tumorigenesis and extends the lifespan of pRB (+/-)mice. Nature Genetics 18 360-364.

Yoshino A, Katayama Y, Ogino A, Watanabe T, Yachi K, Ohta T, Komine C, Yokoyama T \& Fukushima T 2007 Promoter hypermethylation profile of cell cycle regulator genes in pituitary adenomas. Journal of Neurooncology 83 153-162.

Zhang X, Horwitz GA, Heaney AP, Nakashima M, Prezant TR, Bronstein MD \& Melmed S 1999 Pituitary tumor transforming gene
(PTTG) expression in pituitary adenomas. Journal of Clinical Endocrinology and Metabolism 84 761-767.

Zhu J, Leon SP, Beggs AH, Busque L, Gilliland DG \& Black PM 1994 Human pituitary adenomas show no loss of heterozygosity at the retinoblastoma gene locus. Journal of Clinical Endocrinology and Metabolism 78 922-927.

Zhu X, Wang J, Ju BG \& Rosenfeld MG 2007 Signaling and epigenetic regulation of pituitary development. Current Opinion in Cell Biology 19 605-611.

Zhu X, Mao X, Hurren R, Schimmer AD, Ezzat S \& Asa SL 2008 Deoxyribonucleic acid methyltransferase $3 \mathrm{~B}$ promotes epigenetic silencing through histone 3 chromatin modifications in pituitary cells. Journal of Clinical Endocrinology and Metabolism 93 3610-3617.

Zindy F, den Besten W, Chen B, Rehg JE, Latres E, Barbacid M, Pollard JW, Sherr CJ, Cohen PE \& Roussel MF 2001 Control of spermatogenesis in mice by the cyclin D-dependent kinase inhibitors p18(Ink4c) and p19(Ink4d). Molecular and Cellular Biology 21 3244-3255.

Zou H, McGarry TJ, Bernal T \& Kirschner MW 1999 Identification of a vertebrate sister-chromatid separation inhibitor involved in transformation and tumorigenesis. Science 285 418-422.

Received in final form 1 November 2008

Accepted 5 November 2008

Made available online as an Accepted Preprint 5 November 2008 